\title{
The living dead? The construction of people with Alzheimer's disease as zombies
}

\author{
SUSAN M. BEHUNIAK*
}

\begin{abstract}
In the literature on Alzheimer's disease (AD), scholars have noted how both the disease and the people who are diagnosed as having it have been stigmatised. I argue here that the AD stigma is of a specific sort - it is dehumanisation based on disgust and terror. Although the blame for negative perceptions of people with AD has been placed on the biomedical understanding of dementia, I argue that strong negative emotional responses to $\mathrm{AD}$ are also buttressed by the social construction of people with AD as zombies. To illustrate this point, this paper identifies seven specific ways that the zombie metaphor is referenced in both the scholarly and popular literature on $\mathrm{AD}$. This common referencing of zombies is significant as it infuses the social discourse about $\mathrm{AD}$ with a politics of revulsion and fear that separates and marginalises those with AD. It is in recognising the power of this zombie trope that its negative impact can be actively resisted through an emphasis of connectedness, commonality, and inter-dependency.
\end{abstract}

KEY WORDS - Alzheimer's disease, zombies, social construction, disgust, dependence, stigma, dementia.

\section{Introduction}

The ultimate horror in science fiction is neither death nor destruction but dehumanization, a state in which emotional life is suspended, in which the individual is deprived of judgment. (Carlos Clarens in Russell 2005: 23)

People with dementia can be treated as already dead and as walking corpses to be both pitied and feared, despite their obvious signs of life. (Aquilina and Hughes 2006: 143)

In an age of increased sensitivity to the social and political harms caused by stereotypes, stigma, and discrimination based on disease, it is disconcerting to find that frequent and overt references to zombies lace both scholarly and popular accounts of Alzheimer's disease (AD). Book titles such as Alzheimer's Disease: Coping with a Living Death (Woods I989) and

* Department of Political Science, Le Moyne College, Syracuse, New York, USA. 
The Living Dead: Alzheimer's in America (Lushin I990) clearly link patients with ghouls. The destruction of the person and the animation of the corpse is another theme: Cohen and Eisdorfer (I986) referred to the 'death before death', Smith to the 'funeral that never ends' (ig92: 49) and Fontana and Smith (Ig89) to the 'self that unbecomes'. And then there is the drawn-out nature of this dying: Death in Slow Motion: A Memoir of a Daughter, Her Mother, and the Beast called Alzheimer's (Cooney 2004), and A Curious Kind of Widow: Loving a Man with Advanced Alzheimer's (Davidson 2006).

The problematic association of zombies with AD patients has been explicitly noted in scholarly writing only once. In 'The return of the living dead: agency lost and found?' Aquilina and Hughes (2006: I43) compared examples of quotes about zombies with those about patients with $\mathrm{AD}$ and concluded that it is difficult to discern which description refers to monsters and which to human beings, and that this confusion can cause real harm to people with $\mathrm{AD}$. That AD is defined as a confused state between life and death has been noted by Matthews (2006: I63), who cautioned that 'it is easy to fall into thinking of dementia as a kind of "living death", Herskovits (I995: I60) came close to making explicit reference to zombies in noting that the 'discursive controversy focuses on the figure of the Alzheimer's "victim" as dehumanized monster'. Other researchers have focused on the stigma associated with AD, not naming the zombie metaphor except by way of implication. Sabat (2003) critiqued the many ways that public discourse imposes 'malignant positioning' on patients with AD; Herrick, Pearcey, and Ross (I997) regarded stigma as 'contagious'; and Jolley and Benbow (2000: II7) compared AD with cancer, tuberculosis, AIDS, and leprosy since as a label it 'commands fear before sympathy, because it has been marketed largely through its most debilitating, demeaning and despairing features'. In his study of the history of AD, Fox (I989: 58) began by noting that AD 'conjures up images of a hideous, debilitating condition', and that others have called AD 'the disease of the century' and 'the mind robber'. Whether or not these references to zombies are explicit or implicit, however, there has been no study of the specific ways in which AD patients have been socially constructed as zombies; a task I address here.

That the social construction of people with $\mathrm{AD}$ as zombies is highly problematic stems from the horrifying zombie trope in popular culture. Director George Romero's film Night of the Living Dead and its sequels have been the subjects of much analysis; scholars have suggested that his zombies are metaphors for consumerism (Harper 2002), race relations (Wood 2008), and the United States of America's (USA) involvement in Vietnam (Higashi i99o). My approach, however, is the exact opposite of these film deconstructions. I neither argue that the zombies in the Dead 
films are metaphors or allegories for those with $\mathrm{AD}$, nor that $\mathrm{AD}$ is actually a social construction rather than a medical condition. Rather, I argue that the frightening celluloid images of fictional characters called zombies have leaked into the popular and scholarly discourse about real people who have Alzheimer's disease, constructing them as animated corpses and their disease as a terrifying threat to the social order. The zombie-AD patient connection is not therefore a case of art imitating life, but of a far more complex cultural relationship. The zombie instils fear by drawing from cultural anxieties, and then reflecting them back to the population that in turn breaths life and strength into them by applying this fictional representation to social realities. In this way, the social construction of those with $\mathrm{AD}$ as zombies generates not only the negative stereotypes and stigma associated with people constructed as 'other', but also the emotional responses of disgust and utter terror ( $c f$. Scholl and Sabat 2008). It is this politics of revulsion and fear that directly infuses the discourse about AD and shapes it.

This paper explores how the fusion of AD patient with zombie has taken place and its ramifications. The first part provides background information on social construction theory, the nature of stigma, and the terrifying image of the zombie as developed in film. In the second part, a detailed account of the seven ways that the zombie trope is applied to patients with $\mathrm{AD}$ is presented in order to demonstrate the easy slippage between monsters and people. The third part of the paper analyses the unsettling implications of this stigmatised view of persons with $\mathrm{AD}$, and highlights the roles played by disgust and fear in this dehumanisation.

\section{Background: social construction, stigma, and zombies}

The lens of social construction theory is revealing when applied to patients with AD. Berger and Luckman's classic work, The Social Construction of Reality, questions how 'subjective meanings become objective facts' (I966: I8), the elusive process by which the fictional characters of zombies can be referenced to describe real people with AD. Berger and Luckman's theorising about the power of language is helpful here: 'Language is capable not only of constructing symbols that are highly abstracted from everyday experience, but also of 'bringing back' these symbols and appresenting [sic] them as objectively real elements in everyday life (1966: 40). Their point is that reality is not composed of objective facts but of subjective appraisals that are socially agreed upon to serve as knowledge. Once institutionalised, this reality is then experienced as objective (1966: 60). I use social construction theory here not to argue that $\mathrm{AD}$ is itself a social 
construct but to suggest that knowledge of $\mathrm{AD}$ has in part been constructed by reference to the images and language associated with the fictional characters called zombies.

Harré and Moghaddam (2003: 4-5) built on social construction theory by emphasising the importance of distinguishing between actions that are logically possible and those that are socially possible, thereby emphasising how the social context narrows a person's choices. They invited awareness of the 'positioning triangle'; the interdependent relationship between a person's socially-prescribed position, the person's speech and other acts, and the person's contribution to the storyline. This triangle reveals the limited nature of the person's real choices, the social meaning of every act, and how narratives tend to follow an established script. In the case of people with AD, the script is literally lifted from the world of film. Applied to the study of people with AD, social construction theory has produced some troubling findings. Kitwood used the term 'malignant social psychology' to describe how patients with AD are first compromised and then judged negatively when they react to negative positioning with hostility, learned helplessness, or depression (Kitwood i99o). Sabat (2003: 85) built on Kitwood's observation to develop a theory of 'malignant social positioning' that encompasses two positions germane to AD. First, there are interaction cases, 'wherein what one person says positions another person', for example by highlighting their deficits, and second, reflexive cases, 'wherein one positions him or herself' in response by either rejecting or accepting what is said. Sabat concluded that some forms of positioning can be malignant, 'that is to say dangerous, insofar as they can have negative effects not only upon the ways in which the person with AD is seen by others, but upon the ways in which the person with AD is subsequently treated and may come to see him or herself to one or another degree' (2003: 86).

It has been noted that 'at the heart of the [AD] diagnosis lurks some sort of evaluative judgment' (Hughes, Louw and Sabat 2006: I), and that judgment is widely viewed to be stigma (e.g. Benbow and Reynolds 2000; Herskovits I995; Jolley and Benbow 2000). Stigmatisation is the process of devaluing an attribute or condition, and through this, the individual who possesses it. Because the disdain is aimed at all individuals who share the specific feature, they become unwilling members of a stigmatised group (Schneider 2005: 474). While some groups are stigmatised for being presumed to be responsible for their condition or for posing a danger to others, the stigma assigned to people with AD appears to come more from their disruptiveness, their lack of aesthetic value, or what Goffman (I963) calls 'courtesy stigma', i.e. catching the stigma of AD by close association, and from interaction problems such as strained communication. 
AD scholars have placed much of the blame for the powerful stigma regarding dementia on the dominance of the biomedical understanding of the disease (Kitwood 1997; Kontos 2003; Lyman 1989; Netten 1993). This model reinforces the notion of the patient with $\mathrm{AD}$ as a non-person, i.e. one whose brain has been destroyed by the disease and who therefore no longer exists as a person but only as a body to be managed. The practical consequences of this view are profound: attempts to communicate with the patient stop, life-prolonging treatment is withheld, and force is used to control undesirable behaviours. Thomas Kitwood (1997), who was at the forefront of those who challenged this biomedical approach, argued in favour of a person-centred approach to $\mathrm{AD}$ that assumes that the person is present and approaches $\mathrm{AD}$ as a condition shaped and defined by the social and interpersonal contexts rather than by neurological changes alone. In this, he maintained that malignant positioning within the care environment is not only 'deeply damaging' to personhood but may even undermine the physical wellbeing of patients (1997: 46). He identified no less than i7 malignant practices: treachery, disempowerment, infantilisation, intimidation, labelling, stigmatisation, outpacing, invalidation, banishment, objectification, ignoring, imposition, withholding, accusation, disruption, mockery, and disparagement. His point was that what is understood by members of the medical profession as symptoms of the disease may in fact be the result of how AD patients are treated, and how they are treated is the result of how the disease is socially constructed.

Even though Kitwood and other person-centred theorists identified the biomedical model of $\mathrm{AD}$ as a prime source for the stigmatisation of $\mathrm{AD}$ and patients, I suggest that the biomedical model does not fully account for the negativity of responses to AD. Rather, a simplified view of the treatment and care implications of the model have been supplemented by the zombie metaphor to generate a social construction of $\mathrm{AD}$ patients that is much worse than even the stigmatisation that has been noted in the literature. It is worse because the social construction of $\mathrm{AD}$ patients as zombies has infused stigma with disgust and terror. The result, then, is stigma in a particular form, delegitimisation, which Bar-Tal defined as: 'categorisation of groups into extreme negative social categories which are excluded from human groups that are considered as acting within the limits of acceptable norms and/or values. Delegitimisation may be viewed as denial of (the) categorised group's humanity' (1989: I70).

The exclusion of delegitimised individuals is permanent and accompanied by intense negative emotions (Bar-Tal I989: I7I). Social, political and legal institutions, rather than resisting these social norms, instead support and help to enforce them. In the case of people with $\mathrm{AD}$, this can be seen in the discussion of whether previously-signed advanced directives, 
living wills and do-not-resuscitate orders should continue to have weight because the legal person who signed or agreed to them no longer exists although the body still lives (see Dresser i995; Kuhse 200I). Even norms regulating truth telling and consent are undermined by the assumption that $\mathrm{AD}$ is so dreadful a diagnosis that the news should not be shared with the patient; the stigma being so powerful that one study suggests that patients are informed of the diagnosis in only 40 per cent of the cases (Johnson, Bouman and Pinner 200o).

To reiterate, the connections drawn between zombies and AD patients help to explain the origins of the intense form of stigma applied to AD, but the zombie trope applied to people with $\mathrm{AD}$ is a very particular one - that of Romero's films - although the 'zombie' has a longer history than the cinema. Gothic literature like Mary Shelley's Frankenstein and Bram Stoker's Dracula set the stage for imagining fictional characters whose reanimation from the dead disturb cultural norms, beliefs and practices about how and even whether such a power should be used, the clarity of the line that divides the living from the dead, and what it means to be human. The ethical questions posed are even more poignant in the case of zombies because they are neither monsters nor supernatural vampires, but ordinary people who were once just like us, and this makes them 'rather more fully and disconcertingly human' (Paffenroth 2006: 3).

Stories about zombies originated in West Africa and travelled to Haiti. Journalist William Seabrook's Magic Island (I929) described how voodoo rites could reduce a living person to what appeared to be the state of death and then reanimate the victim as a mindless, soulless drone. Zombie stories spread in the USA with the return of marines who had served during the US occupation of Haiti from i9I5 to i934. Such tales were reinforced by Bela Lugosi's role as a slave master in the film White Zombie (I932), which portrayed zombies as empty vessels whose labour and will were appropriated. As Dendle (2007: 46) noted, the Haitian zombie that was 'brought back to the dead to toil in the fields and factories' resonated with the Depression-era crisis in American capitalism, the connection between meaningful work and dignity, and 'burned-out souls standing in lines at soup kitchens'. In The Ghoul (I933) the location moved to Egypt, and in Revolt of the Zombies (1936) the scene shifted to the Far East, yet the zombies remained cast largely from the same mould, and the proliferation of films that followed were considered grade B silliness. That was to change with the I968 release of George Romero's film, Night of the Living Dead (Russell 2005).

With Romero's entry into the genre, the zombie character became utterly horrifying; a being so awful and so layered in meanings that Romero's films were read and debated as social commentary. In his 
original trilogy of Night of the Living Dead (1968), Dawn of the Dead (1978), and Day of the Dead (I985), Romero recharacterised the zombie as a 'dispossessed' entity, the exact opposite of the enslaved zombie (Gunn and Treat 2005: 153). No longer were zombies controlled by a mastermind; now they were frightening ghouls who rose from the dead with the relentless drive to feed on the flesh of others who, once bitten, became zombies themselves. Romero's zombies are likened to what Dante called 'the suffering race of souls who lost the good of intellect' (Ayoub 2006: I8). That is, the reanimated corpses appear to be only marginally alive; they move stiffly and slowly, recognise no one, do not respond to their own names, and are often rotting or mutilated. They are cannibals who spread whatever contagion they carry to their prey and so their numbers increase in epidemic proportions. In more recent films like 28 Days Later (2002), 28 Weeks Later (2007), and Zombieland (2009), zombies are re-imagined as hyperactive and fast. But it is Romero's zombie - slow, autonomous, lacking cognition but recognised by its victims, lumbering about as a voracious body, and spreading in overwhelming numbers - that becomes the touchstone for much of the cultural responses to AD.

How, indeed, to read the zombie? Their voracious appetites and need to consume evoke critiques of consumerism gone wild. Their herd mentality and unfocused stares harken to the empty eyes of video gamers. Their liminal status between the living and the dead seems to be a metaphor for patients whose bodies remain alive tethered to machines but whose cognition appears lost. Their slow pace, grey pallor, rotting flesh and lack of memory suggest the ageing process. Although a thoroughly familiar figure across western cultures, the zombie contains a multitude of meanings, layers, critiques and fears. Reference to the zombie metaphor is currently in vogue and usually in playful ways. 'Zombie' is used as a descriptor of those who text while walking (Bruce 2010) or who sit for too many hours in front of a computer screen (Higgins 2010). The word has also been applied to: unprofitable banks shored up by government support; synthetic ribonucleic acid cells that are inserted 'into living cells to do their bidding' (Macfarlane 2008); social workers who ' go through the motions by filling in forms' (Rogowski 2008); and erroneous medical 'facts' that just will not go away (Thornhill, Clements and Neeson 2008). Zombies have invaded even classic literature, as Grahame-Smith (2009) demonstrates in his revision of one of Jane Austen's novels in Pride and Prejudice and Zombies. In addition, however, there are less humorous applications such as tagging as 'zombies' both those who are brain-damaged (see Burg 1972: 1992) and the overly-medicated elderly residents of nursing homes ( $c f$. Pappenroth 2006). There are also references to people in a persistent vegetative state as the 'living dead' (Laurance 2010; Sparrow 2006; Thompson 2006). 
As Grossman (2009) wrote in Time of the recent ubiquity of zombies in pop culture:

It's not easy to put your finger on what's appealing about zombies. Vampires you can understand. They're good-looking and sophisticated and well dressed. They're immortal. Some of them have castles. You can imagine wanting to be a vampire or at least wanting to sleep with one. Nobody wants to sleep with zombies. They're hideous and mindless. They don't have superpowers. Their only assets are their infectiousness, single-minded perseverance and virtual unkillability.

In applying the label of 'zombie' to those with AD, I want to suggest that the destructive power of the biomedical model of disease is magnified when combined with the 'undead' metaphor. For example, in his study of AIDS patients in South Africa, Niehaus (2007: 845) noted 'the construction of persons with AIDS as "dead before dying" as an outcome of the manner in which biomedical discourses have articulated with religious and popular ones'. He claimed that the understanding of AIDS 'as a fatal terminal disease carries with it as much symbolic weight as the popular association of persons suffering from AIDS with lepers and zombies' (2007: 845). To better understand the stigma of AIDS in South Africa, Niehaus rejected the explanation of an association with sexual promiscuity in favour of its more powerful association with death, arguing that persons with AIDS are literally viewed as 'corpses that live' (2007: 848). The same can be said of persons with AD. The biomedical model alone cannot account for the degree of terror that surrounds AD. Although a terminal disease can invoke a dread of death, it is not so much death by AD that terrifies but the proposition that patients will be dehumanised through social construction as the 'living dead'.

I therefore turn to the ways in which the images of zombies from film have been specifically drawn upon, whether deliberately or inadvertently, to socially construct $\mathrm{AD}$ as a terror-inspiring plague and people with AD as less than human. When applied, the resulting stigma is powerful enough to replace compassion with fear, hope with despair, and empathy with disgust. The result of this social construction is the dehumanisation of people with AD.

\section{The social construction of $\mathrm{AD}$ patients as zombies}

Seven characteristics are associated with zombies by Romero's trope: exceptional physical characteristics, lack of self-recognition, failure to recognise others, cannibalisation of living human beings, the exponential spreading of this plague, the resulting horror of those still unafflicted, and 
the zombie's overwhelming hopelessness that makes death a preferred alternative than continued existence. The AD literature from Englishlanguage medical journals was searched for references to these seven characteristics, not with the goal of documenting every example, but to provide illustrations of how the zombie metaphor is reproduced.

Three aspects of the zombie trope - appearance, loss of self, and loss of the ability to recognise others - have been directly applied to people with AD. Three other aspects - the epidemic threat, widespread cultural terror, and death as preferable to becoming an animated corpse - are referenced by way of implication in describing the disease itself. The remaining aspect of the zombie trope - cannibalism - is applied both to patients and to the affect their disease has on others. Although these seven characteristics are canvassed separately below, two important points emerge from their collective examination. First, however frightening the stock image of the zombie, some of its characteristics describe the symptoms of those who are believed to have $\mathrm{AD}$ : wandering, shuffling, moaning, not knowing who they are, and not recognising loved ones. The accuracy of these attributes does not, however, excuse the usage of the zombie trope because it enables what Nussbaum (2010: I5) calls 'projective disgust'. If zombies are disgusting (and they are), and if people with $\mathrm{AD}$ look like zombies (and they may), then people with $\mathrm{AD}$ are also disgusting. As the actor Dennis Hopper phrased the sentiment in Land of the Dead: 'Zombies, man. They creep me out'. It is in invoking the metaphor of the 'undead', then, that we risk slipping beyond the characteristics of $\mathrm{AD}$ to infuse people with all the attributes of a zombie plague.

Secondly, no single characteristic links those with AD to zombies but rather the cumulative stock image or profile. The seven characteristics of zombies form a powerful metaphor that is utterly recognisable and so familiar that only a few need to be invoked to imply the others. This is so whether the zombie metaphor is explicitly made or not, and whether the reference is an attempt at clever word play or not. In fact, although I use examples from the literature on $\mathrm{AD}$ to exemplify how zombie imagery is referenced, I do not argue that this imagery is maliciously invoked. Indeed, titles such as, 'Hospice for the living dead ... mental illness and our practices of care' (Schuman i99I), 'Caring for the 'living dead' (Baher 2004), and 'Beyond appearances: caring in the land of the living dead' (Dunkle 1995), are all found in nursing journals that are presumably dedicated to improving medical and social responses to the people who are dying. My intent, then, is not to disparage those who have used the zombie metaphor in reference to $\mathrm{AD}$, but to raise awareness of its almost casual infusion into the discourse about $\mathrm{AD}$ in order to question its impact and whether this should in fact continue to be the norm. 


\section{Appearance}

James Twitchell (I985: 26I) wrote that, 'The zombie is really a mummy in street clothes.... They simply lumber about ... shuffling their feet like dateless high school students before the prom' (cited in Russell 2005: 7). As depicted in Romero's classic films, zombies stalk their prey in frightening silence or groaning inarticulately. Their bodies lumber in a slow shuffle with arms raised as they reach out to claim their victim. What they lack in speed they make up for in determination - they are relentless and never stop their hunt for human flesh. Given that they are also 'dead', their pallor is grey, their hair is unkempt, and their dress soiled and tattered. As opposed to other fictional monsters with superpowers or refined skills, zombies may at first appear to be rather pathetic monsters, but their seemingly benign appearance is part of their horror. They look human but act otherwise and, as the character Barbara noted in the I990 remake of Night: 'They're us and we're them' (Russell 2005: 69). And their slowness of movement as they hunt for victims is of no comfort. Max Brooks, author of two novels on zombies, has stated in an interview that the slow zombie is undoubtedly more terrifying than the fast zombie because the hunted know that when they sleep, they will eventually be caught $(c f$. reviews of Carroll 2006; Cruz 2006).

There is an obvious and uncomfortable overlap between the characteristics of zombies and persons with $\mathrm{AD}$. The slow shuffle, the inarticulate moans, the relentless walking, the dishevelled appearance, and references made to the coming of the 'grey hordes' as the baby-boom generation ages make it easy to apply zombie descriptors to real people. Journalist Lauren Kessler, author of Dancing with Rose, a sympathetic book on AD, worked for months as an aide on an AD unit. Her recollection of her initial stigmatised understanding of AD is brutally frank: " When you lost your mind, you lose your self", I would have said. "Alzheimer's makes people into zombies", I would have said. "The walking dead. Give me anything, but spare me this disease I would have said" (Kessler 2007: 223). The metaphor is used earlier in the book when she recalls a conversation that she had with a new aide, a woman with a 'haunted' expression who told her during a break from the end-stagers' unit, 'If this is what it's like, I won't be able to take it. It's Night of the Living Dead over there' (Kessler 2007: I59). And as illustrated in the introduction to this paper, scholars also apparently feel free to apply the living dead metaphor when they study people with AD.

\section{Loss of self}

As Brendan Riley, professor of a course titled 'Zombies in Popular Media' remarked, 'there is this sense of [zombies] being the people you 
know - but they're not. And that's what's scary' (cited in Vance 2007: Aro). The twilight condition of both the zombie and the person with AD raises the thorny question of what it means to be human. When cognition has gone, is the person gone even though the body remains animated? What indeed is the connection between the brain and the body? Even the concept of 'brain death' plays into the zombie metaphor; after all, the only way to kill a zombie permanently is with either a bullet or a blow to the head, the general wisdom being, 'kill the brain, kill the zombie'. What does this mean, then, for the person whose brain is 'invaded' by tangles and plaques? It is the biomedical model of $\mathrm{AD}$ that suggests that when the brain has failed and cognition has gone, there is only the body that remains. AD patients have been characterised as 'being a blank' (Phinney and Chesla 2003: 292), as suffering from a 'loss of self' (Cohen and Eisdorfer 1986), and as being 'increasingly devoid of content' (Fontana and Smith ig89: 36). This is a view supported in the popular literature as well. Author Jonathan Franzen, in describing his father's eventual death from $\mathrm{AD}$ wrote, 'but in the slowmotion way of Alzheimer's, my father wasn't much deader now than he'd been two hours or two weeks or two months ago' (200I: 9I). And an AD patient identified as Jean observed that the fear is not about death, but 'the loss of oneself while you're still alive' (Snyder I999: 57). Dimitry Rimsky (2003) wrote in a book review, 'We do not grieve for the loss of a body, we grieve over the loss of a person and with Alzheimer's disease we lose the person long before the body dies'. The loss of self, then, translates into a loss of humanity - a struggle that is echoed in Max Brooks's (2006) novel about zombies, World War Z. One of the 'interviewed' subjects recalled:

The psychological aspect I found the most maddening. People wanted so badly to anthropomorphize the walking blight ... it seemed that everyone was trying desperately to find some shred of a connection to their enemy, to put a human face on something that was so unmistakably inhuman. (2006: 196)

As applied to $\mathrm{AD}$, the question is often phrased as: if the person no longer exists, who or what is left? In this, zombies and patients with AD share a status of being 'not quite'; they are neither fully dead nor do they appear to be fully alive. In experiencing a loss of self, it is the spirit that is presumed to have departed although the body continues on: this loss of the self signals that human identity has been lost as well (Boon 2007: 36).

\section{Inability to recognise others}

Connected to the loss of self is the loss of the ability to recognise others. Perhaps the most disconcerting and terrifying aspect of zombies is that they no longer recognise those they once knew and loved. One of the most memorable moments in Night of the Living Dead' is when the zombified 
Johnny - who was killed in the film's opening reel - returns from the dead to drag his sister out of the house' (Russell 2005: 69). The horror on the screen is partly that of a brother pulling his sister from safety to her death and partly of a young girl using a garden trowel to kill her mother who had tried to nurse her back to health. Those once familiar now see us as strangers and they also pose a danger.

People with advanced AD may also fail to recognise family members and other familiar people. That they may pose a danger not only to themselves but to others is a subject in much of the literature for care-givers. For example, a handbook for AD care-givers sold on the Alzheimer's Association website (http://www.alz.org/coachbroylesplaybook.pdf) is in fact a sensitive guide that assumes the personhood of the patient and offers useful suggestions, but it still invokes the zombie horror in its use of sports and war terminology. It instructs readers to, 'know your opponent' (meaning the disease), and has sections titled 'survival tips' and 'protecting the quarterback'. During the middle stage of the disease, care-givers are warned that, 'everyone's safety has to be the top concern right now' (Broyles 2006: 29). Aggressive behaviour is predicted as the patient 'may try to hit, bite or push you when you try to help her take a bath or get dressed. She may begin to make threats or curse at you during her care' (2006: 32). Advice to care-givers is drawn from the biomedical view of $\mathrm{AD}$ when they are cautioned to remember, 'the changes in how she acts are caused by brain damage. She cannot control how she acts. It's part of the disease!' (2006: 32), and finally, 'no matter what you and your doctor try, in the end Alzheimer's will win' (2006: 75). AD is depicted as a relentless monster.

\section{Cannibalism}

Refusing to skirt the issue of the zombie's physicality - both in its monstrous form as a reanimated corpse and in its newly threatening form as a flesh-eating creature - Romero brought an uncompromising realism to the genre and added a previously unheard of dimension to the zombie myth: cannibalism. (Russell 2005: 67)

The cannibalism of zombies is referenced in two different ways in the AD literature, as a descriptor of what the disease does to the 'victim', and what the AD patient does to the lives of others. In Thomas DeBaggio's moving account of his own struggle with $\mathrm{AD}$, Losing My Mind: An Intimate Look at Life with Alzheimer's, he draws on the metaphor of cannibalism to describe the destructive power of the disease: 'Although subtle in attack, Alzheimer's is the closest thing to being eaten alive slowly' (DeBaggio 2002: 4I). His is not the only reference seemingly drawn from zombie films. Another sufferer of the disease and author, Diana McGowin, describes being 'dragged' further into the disease (McGowin 1993: 87). And in what is 
surely an unintentional reference to cannibalism, a daughter describes AD patients like her mother as 'unappetizing' (Cooney 2004: 93). Even scholarship uses the metaphor of the disintegrating corpse. For example Silberfeld (2001 : 303) wrote: 'Incompetent persons with dementia perhaps have enjoyed the same feasibility set, but now it has "decomposed" in a fashion that makes it hard to specify which options of that set remain'. Fontana and Smith (1989: 40) referred to daily rituals that are in 'decay', and the 'last remnants', 'last vestiges' and 'scarce remains' of the self as the disease progresses. In context, such references are indeed innocent descriptors of $\mathrm{AD}$ and not deliberate allusions to zombies, yet the language used serves to reinforce the unspoken imagery of the 'undead'.

Others use the cannibalism metaphor to describe the affects of the disease on others - not in the sense of the aggressive behaviour of AD patients but referring to the toll their care exacts on the lives of their care-givers. As one commentator wrote about zombies in film: '[we] must remember that family members, when they die, don't merely become zombies, they eat each other' (Wood 2008). This observation becomes a sentiment shared by a number of observers who have described how the time and lives of care-givers and family members are consumed by the disease. David Shenk (200I: 87) was explicit: 'The unique curse of Alzheimer's is that it ravages several victims for every brain it infects' - notice his reference to $\mathrm{AD}$ as an infection. Jonathan Franzen (2001: 87) stated that although it was his father who had $\mathrm{AD}$, paradoxically it was his mother in her role as caretaker 'who slowly and surely lost her self'.

\section{Epidemic proportions}

Whereas the zombie plague is imagined to spread like a virus by the infected biting the healthy, $\mathrm{AD}$ is a neurological condition that one develops independently of others. AD is not contagious, yet in exploring whether there is a genetic link between family members, some have referred to $\mathrm{AD}$ as if it were: 'Alzheimer's is catching, often passed from parent to child through faulty genes' (DeBaggio 2002: I89). As a character in the film Dawn of the Dead (1978) said of the zombie plague, 'It's everywhere'. Rather than the viral connection, it is the unstoppable nature of $\mathrm{AD}$ and its epidemic proportions that link it with the zombie plague. It has been estimated that in 200626 million individuals in the world had $\mathrm{AD}$ and that the number will quadruple worldwide by 2050 (interview with Ron Brookmeyer 2007). The AD literature is replete with predictions of the doomsday disaster that lies ahead as Alzheimer's claims millions upon millions of 'victims' (Anon I990; Baker 2007: 8; Robertson I991; Shenk 2003: 4-5; see Cruickshank's critique, 2003: 25-33). 
Even mathematicians have playfully encouraged this blurring of the divide between fiction and reality in using the tools of epidemiology to ask whether humanity could survive a zombie outbreak - with the dismal understated finding 'not promising' (Smith 2009: E297; Thompson 2009). This fixation on the exponential growth of the numbers recalls Russell's (2005: 69) analysis of the zombie plague: 'Romero takes the paranoid fears of Invasion of the Body Snatchers - in particular its vision of the mass as a terrifyingly homogeneous entity - and multiples them several times over'. As suggested in film, with each tick of the clock we step closer to being swallowed by the plague although it is uncertain when exactly each of us will fall victim. In zombie lore, it is a bite that can make a person become a zombie at any time (Wood 2008); in the AD 'crisis', it is age that brings us closer and closer to the disease (an exaggerated belief since only one-in-ten older Americans are diagnosed with AD) (Cruickshank 2003: $3^{8}$ ).

For AD patients, it is not the physical dying that is contagious, but the 'social death' that accompanies the stigma of the diagnosis; a stigma that spreads from the individual patient to family and care-givers (Herskovits I995: I52). One woman with AD said, 'We've never tried to hide that I have Alzheimer's, but everyone acts like they don't want to get near because they might catch it' (Snyder I999: 22). The zombie and AD epidemics both constitute threats to the social order. One aspect of ageism is to vilify the old for economic strains that come from dependency as if they are undeserving of social concern, made no contribution to society during their lives, and are now sucking the life force out of the community. Cruickshank (2003: 25) noted how the growth of the older population has been negatively reinterpreted in the popular and scholarly literature as a 'menace' that 'threatens the non-old'. She cited the negative terms favoured by conservatives to describe increased longevity: a 'time bomb', 'apocalyptic demography', 'disaster', 'onslaught', 'flood' and of course 'epidemic' (2003: 26-7). Badley (I995: 75) observed how this fear is reflected in zombie films: 'Romero's metonymy in part responds to anxieties about a health care system of seemingly reversed priorities when the old and the wealthy (the dead) cannibalize the young and powerless (the living) for healthy organs or foetal tissue'.

\section{Cultural terror and disgust}

Although the death scenes in zombie films are scary enough, it is the threat of becoming one of the living dead that heightens the viewers' anxieties. To be undead is to be denied the finality and peace that comes with death; to be undead is to become less than human; to be undead means being feared rather than mourned. 'Zombie remains a devastating word, 
unrivaled in its power to conjure up so many memories or emotions' (Brooks 2006: I). In an article that posits a zombie-AD connection, Aquilina and Hughes explained the power of the zombie to invoke horror: 'We are terrified as observers because we can identify with the awful situations that these creatures are in' (2006: I43). Although the prospect of a zombie attack, of being eaten, and of being killed are all frightening in and of themselves, the real dread that spreads throughout the film audience is that 'of being turned into one of them' (Larkin 2006: 20).

That a diagnosis of dementia has taken on a similar dread has also been noted. As Herskovits (I995: I48-9) explained, it is the construction of Alzheimer's disease as a pathology that has replaced the prior understanding that senility in old age was expected and even socially acceptable. When memory loss was viewed as a natural part of the ageing process, any problems associated with it called for a social response, but when this loss was blamed on a disease, the needed response became clinical. Constructed in biomedical terms, $\mathrm{AD}$ was now a disorder that called for research, pharmaceuticals and interventions: 'With the popularization of Alzheimer's, the subjective experience of aging and of "senility" have become increasingly horrific and monstrous; we are all afraid of losing our minds as we grow old' (Herskovits 1995: 148). The consequence is that no matter our age, we are all subtly anxious about any failures of memory (Post 2006: 224). Any experience of forgetfulness, any 'senior moment', and any confusion are tallied as growing evidence that we are beginning 'to lose our minds'. The consequences are devastating because the loss of memory is a loss of power that gives others the ability to punish those who are forgetful (Post 2006: 224). The person with failed memory is mocked, humiliated, controlled, questioned and institutionalised. The 'demented' person loses autonomy, dignity, respect and control. It is no wonder then, that AD 'commands fear before sympathy' (Jolley and Benbow 2000: I I7). Kessler (2007: I44) observed: 'When you spend your days around people with this disease, despite the amazing moments and the times you feel like Mother Teresa on meth, the mantra that runs through your head is: not me not me not me please not me'. $\mathrm{AD}$, unlike other diseases, is regarded as the leprosy of the early 2000s, since it is seen as not only fatal but also dehumanising; the cultural response is not to reach out with compassion but to shrink away in terror.

\section{Death as preferable}

A headline in a popular magazine says it all: 'Alzheimer's: No cure, no help, no hope' (Kitwood I997: 37). If this is the public perception, then it is 
no wonder that death is preferable. This trope is ever-present in zombie films and fiction; the living make pacts to shoot each other and even to kill themselves rather than allow the infected to make them into zombies (Larkin 2006: 20). For instance, in Max Brooks's novel, World War Z, the American soldiers found they were incapable of shooting another soldier so they requisitioned ' $\mathrm{L}$ pills' - lethal pills to take should they risk being infected (Brooks 2006: 294). 'It wasn't long before they began to kill themselves in groups, all those who'd been bitten in a battle gathering at the field hospital to synchronize the moment when they would all pull the trigger' (2006: 296).

In the $\mathrm{AD}$ literature, the theme of 'better dead than get $\mathrm{AD}$ ' is also present. Patient Diana McGowin (i993: I05) wrote: 'I could well understand the desperation of those with serious illnesses who had ended their lives out of fear and uncertainty about the future'. A patient called 'Bea' said, 'I've hoped for a long time now that God would take me' (Snyder I999: 30). Scholars Aquilina and Hughes (2006: I44) wrote that people have asked for and been assisted in committing suicide when they fear or have had such a diagnosis. Perhaps the most famous case of an AD suicide was that of Jane Adkins, who at 54 years of age was in the early stages of her disease and chose to end her life with the aid of Dr Jack Kevorkian (Herskovits i995: I55). A pop culture depiction is also revealing. William Shatner's character Denny Crane, from the television series Boston Legal, feared the diagnosis of AD so much that he preferred to call his condition 'mad cow'. It is a telling commentary when that infectious, degenerative, and often fatal disease could carry with it less of a stigma than AD (see Basting's (2009: 6I-6) different interpretation of this show). And it is a destructive social construction, indeed, that would make death preferable to a life lived with AD.

\section{Discussion and conclusion}

Whether used inadvertently, as metaphor, or as a consciously chosen descriptor, the social construction of people with AD as zombies is a destructive representation of AD because it invites and supports the oppression of human beings by encouraging fear and disgust. An attribute of the zombie trope is that AD is viewed not primarily as a disease but a lethal threat at both the individual and social levels. Individuals who have $\mathrm{AD}$, or who provide care to those who have it, or who live in fear of the diagnosis, are concerned not only about the medical meaning of the disease, but also about social responses to it. As Susan Wendell noted 
regarding the inability of able-bodied people to identify with those who are physically disabled:

Something more powerful than being in a different body is at work. Suffering caused by the body, and the inability to control the body, are despised, pitied and above all, feared. This fear, experienced individually, is also deeply embedded in our culture. (1989: I I2)

Will those with $\mathrm{AD}$ be sympathetically viewed as fully human, worthy of respect, and deserving of compassionate social support, or feared as already dead, lacking in dignity and a costly burden? Such fears are fanned rather than damped down by a metaphor that evokes disgust - a reaction of deep aversion that constitutes 'a fundamental refusal of another person's full humanity' (Nussbaum 2010: xiii). As an object of disgust, the person with $\mathrm{AD}$ is viewed as a 'loathsome contaminant to the body politic' (2010: xiii) and as such becomes vulnerable to targeting and subordination (2010: $\mathrm{xv})$.

Thus constructed as 'other', people with AD are in danger because the zombie metaphor clearly delineates between those who are 'afflicted' and the rest of society. This differentiation makes it possible, even justifiable, to socially marginalise those regarded as 'other', to render them politically invisible, and to use law to discriminate against them. While it is possible that those termed 'others' may evoke sympathy, empathy is not possible when a feeling of kinship has been destroyed (Wendell ig89: I04). In the case of the zombification of those with $\mathrm{AD}$, the possibility is even worse - not only a lack of empathy but also no sympathy as such virtues are overcome by the dual reactions of revulsion and terror. The zombie trope, then, enflames disgust while undermining its two antidotes - respect and sympathy - thus making it difficult for 'imaginative and emotional participation in the lives of others' (Nussbaum 2010: xix). As Anne Davis Basting put it:

I don't pretend that we can eliminate the fear of dementia. We are human, after all. We can, though, learn to feel more than fear. We can learn to feel and act with respect and compassion and to believe in purpose for those with dementia and those who love and care for them. (2009: II)

The zombie metaphor also endangers patients with $\mathrm{AD}$ since it sets them at odds with the notion of death with dignity or, to be more accurate, life with dignity. The euthanasia movement, having evolved through several names and now commonly referred to as the Death with Dignity Movement (Marker and Smith I996), maintains as a core value the right of people to end their lives in a dignified manner. Within this framework, the question can then be posed as to whether it is possible to be socially constructed as a zombie and still be viewed as a person with dignity, or 
whether the zombie trope as applied to people with AD supports an ideology of eugenics. For example, in Judge Reinhardt's opinion for the US gth Court of Appeals (Compassion in Dying v. Washington I996), which determined that a due process liberty interest supports a qualified right to physician-assisted suicide, he wrote: 'A competent terminally ill adult, having lived nearly the full measure of his life, has a strong liberty interest in choosing a dignified and humane death rather than being reduced at the end of his existence to a childlike state of helplessness, diapered, sedated, incontinent'. Could a competent adult, then, write an advance directive that chooses physician-assisted suicide should advanced dementia occur? Disability scholars who critique practices such as physician-assisted suicide as discriminatory argue that, 'oppressive attitudes toward disability distort the possibility of unbiased free choice' (Garland-Thomson 2002: I6). When a person falls outside the realm of 'normalcy' she or he is rendered not only different but 'less than' human.

As negative as the zombie trope is, it is difficult to fight or to resist. Despite what should be the apparent absurdity of using a fictionalised plague of hoards of the flesh-eating undead as a way to conceptualise a devastating disease, it continues to resonate with scholars, care-givers and even people with $\mathrm{AD}$. Given this, one way to undermine the zombie metaphor is to adopt an approach suggested, quite improbably, by zombie films themselves. An inherent difference between zombies and people with $\mathrm{AD}$ is that Romero's zombies are autonomous creatures while people with $\mathrm{AD}$ are dependent human beings. In fact, what makes zombies capable of their grotesque actions is what Fine and Glendinning (2005:6 $\mathrm{I}_{5}$ ) called a 'relational autonomy' that is so exaggerated that they feel nothing for anyone. Zombies are not only independent but also totally lack any sort of human connection and human emotion - illustrating Nussbaum's point about how disgust flourishes in an environment that lacks both sympathy and respect. In contrast, people with $\mathrm{AD}$ are dependent on others, and elicit as well as experience emotional responses. Therefore, resistance to the zombie trope may be strengthened by emphasis on a kind of dependence that is built on sympathy and respect.

'Dependency' is a contested term that can imply burdensomeness, a lack of agency and an inferior position of power (Fine and Glendinning 2005). The common acceptance of this problematic interpretation is found in data from Oregon, where physician-assisted suicide has been legally practised since I998, which indicate that the most common concern of terminally-ill patients is not untreated pain but loss of autonomy (Oregon Department of Health Services 2009). Still, dependency has other more positive connotations: as connectedness among people, as inevitable in the lifecourse, and as experienced as mutual interdependency (Fine and 
Glendinning 2005; see also Baltes I996; Kittay 1999; Tronto 1993). What may help to dislodge the zombie metaphor, then, is to replace a 'minoritising' view of AD with a 'universalising view' (Sedgwick I990). In this perspective, $\mathrm{AD}$ is not constructed as a disease of the unfortunate few but as a disease that affects us all. This point is echoed in zombie scholarship: "in a literal sense, we are all, as living beings, "Undead", (Greene and Mohammad 2006: xiii). Given this, the constituency needed for advancing socially-compassionate responses to those with $\mathrm{AD}$ should not be limited to those most affected, but expanded to include all of society. Thus understood, AD is no longer a private problem but a social issue. Only in this way will what Nussbaum (2010: xviii) calls a 'politics of disgust' be replaced by a 'politics of humanity'.

The understanding that it is connectedness and mutual interdependence that makes us human is echoed in of all places the 2009 film Zombieland. After joining forces with three other people to survive a zombie outbreak, the character named Columbus states at the end of the film that what made their survival possible was that they had each other. He concludes, 'Without other people, well, you might as well be a zombie'. Just as strong human connections are the key to fighting zombies, such respect and sympathy are certainly required to contend with AD. Such a stance would make the application of the zombie metaphor to people with AD not only impolitic but also unthinkable.

\section{Acknowledgements}

An earlier version of this article was presented at the Western Political Science Association's 2009 annual meeting. In revising I benefited from the comments of Professor Daniel Engster of the University of Texas at San Antonio, and the two anonymous reviewers. My thanks to Inga $\mathrm{H}$. Barnello, social science reference librarian, and my student aide Jenna Newburg for tracking down sources that eluded me.

\section{References}

Anon. I99o. Elderly turned into 'zombies'. Nursing Standard, I 4, Iо, 6.

Aquilina, C. and Hughes, J. C. 2006. The return of the living dead: agency lost and found? In Hughes, J. C., Louw, S. J. and Sabat, S. R. (eds), Dementia: Mind, Meaning, and the Person. Oxford University Press, Oxford, I43-6r.

Ayoub, N. C. 2006. Gospel of the living dead: George Romero's visions of hell on earth. Chronicle of Higher Education, 53, II, I8.

Badley, L. I995. Film, Horror, and the Body Fantastic. Greenwood, Westport, Connecticut.

Baher, J. 2004. Caring for the 'living dead'. Nursing Spectrum, 8, I3, 23.

Baker, B. 2007. Old Age in a New Age: The Promise of Transformative Nursing Homes. Vanderbilt University Press, Nashville, Tennessee. 
Baltes, M. 1996. The Many Faces of Dependency in Old Age. Cambridge University Press, Cambridge.

Bar-Tal, D. 1989. Delegitimization: the extreme case of stereotype. In Bar-Tal, D., Graumann, C. F., Kruglanski, A. W. and Stroebe, W. (eds), Stereotyping and Prejudice: Changing Conceptions. Springer-Verlag, New York, I69-82.

Basting, A. D. 2009. Forget Memory: Creating Better Lives for People with Dementia. Johns Hopkins University Press, Baltimore, Maryland.

Benbow, S. M. and Reynolds, D. 200o. Challenging the stigma of Alzheimer's disease. Hospital Medicine, 6r , 3, I74-7.

Berger, P. L. and Luckmann, T. I966. The Social Construction of Reality: A Treatise in the Sociology of Knowledge. Anchor Books, New York.

Boon, J. A. 2007. Ontological anxiety made flesh: the zombie in literature, film and culture. In Scott, N. (ed.), Monsters and the Monstrous: Myths and Metaphors of Enduring Evil. Rodopi, Amsterdam, 33-43.

Brookmeyer, R. 2007. Alzheimer's Disease to Quadruple Worldwide by 2050. Video interview, Io June. Johns Hopkins Bloomberg School of Public Health website, Baltimore, Maryland. Available online at http://www.jhsph.edu/publichealthnews/press_ releases/2007/brookmeyer_alzheimers_2050.html [Accessed 20 July 2010].

Brooks, M. 2006. World War Z: An Oral History of the Zombie War. Crown Publishers, New York.

Broyles, F. 2006. Coach Broyles' Playbook for Alzheimer's Caregivers: A Practical Tips Guide. University of Arkansas, Fayetteville, Arkansas.

Bruce, A. 20ro. Night of the texting undead; accidents involving so-called 'Zombie Texters' on the rise. Here (St John, New Brunswick, Canada), 4 February, A33.

Burg, B. I972. Can they quote AJN as stating, 'brain-damaged are living dead'? American Journal of Nursing, 72, II, I992.

Carroll, S. 2006. Review of World War Z: An Oral History of the Zombie War Audio Book. Strange Horizons, 31 October. Available online at http://www.strangehorizons.com/reviews/ 2006/Io/world_war_z_an_.shtml [Accessed 26 July 20io].

Cohen, D. and Eisdorfer, C. I986. Alzheimer's Disease: The Loss of Self. Norton, New York.

Compassion in Dying v. Washington, United States Court of Appeal, Washington DC, 79 F.3d 790 (9th Cir. 1996).

Cooney, E. 2004. Death in Slow Motion: A Memoir of a Daughter, Her Mother, and the Beast Called Alzheimer's. Harper Perennial, New York.

Cruickshank, M. 2003. Learning to be Old: Gender, Culture, and Aging. Rowman and Littlefield, Lanham, Maryland.

Cruz, G. 2006. Book Review: World War Z. Entertainment Weekly, I5 September.

Davidson, A. 2006. A Curious Kind of Widow: Loving a Man with Advanced Alzheimer's. Daniel and Daniel, McKinleyville, California.

DeBaggio, T. 2002. Losing My Mind: An Intimate Look at Life with Alzheimer's. Free Press, New York.

Dendle, P. 2007. The zombie as barometer of cultural anxiety. In Scott, N. (ed.), Monsters and the Monstrous: Myths and Metaphors of Enduring Evil. Rodopi, Amsterdam, 45-57.

Dresser, R. 1995. Dworkin on dementia: elegant theory, questionable policy. Hastings Center Report, 25, 6, 32-8.

Dunkle, R. M. I995. Beyond appearances: caring in the land of the living dead. Fournal of Christian Nursing, I 2, 3, 4-6.

Fine, M. and Glendinning, C. 2005. Dependence, independence or inter-dependence? Revisiting the concepts of 'care' and 'dependency'. Ageing \& Society, 25, 4, 60 I-2I.

Fontana, A. and Smith, R. W. I989. Alzheimer's disease victims: the 'unbecoming' of self and the normalization of competence. Sociological Perspectives, 32, I, 35-46. 
Fox, P. I989. From senility to Alzheimer's disease: the rise of the Alzheimer's disease movement. Milbank Quarterly, 67, I, 58-102.

Franzen, J. 2001. My father's brain. The New Yorker, 77, 26, 80-91.

Garland-Thomson, R. 2002. Integrating disability, transforming feminist theory. NWSA (National Women's Studies Association) Fournal, I 4, 3, I-32.

Goffman, E. 1963. Stigma: Notes on the Management of Spoiled Identity. Prentice Hall, Englewood Cliffs, New Jersey.

Grahame-Smith, S. 2009. Pride and Prejudice and Zombies. Quirk, San Francisco.

Greene, R. and Mohammad, K. S. 20o6. (Un)dead (un)certainties. In Greene, R. and Mohammad, K. S. (eds), The Undead and Philosophy: Chicken Soup for the Soulless. Open Court, Chicago, Illinois, xiii-xvi.

Grossman, L. 2009. Zombies are the new vampires. Time, 9 April. Available online at http://www.time.com/time/magazine/article/o,9I7I,I890384,oo.html [Accessed I9 February 2009].

Gunn, J. and Treat, S. 2005. Zombie trouble: a propaedeutic on ideological subjectification and the unconscious. Quarterly fournal of Speech, 91 , 2, I44-74.

Harper, S. 2002. Zombies, malls, and the consumerism debate: George Romero's Dawn of the Dead. Americana: Fournal of American Popular Culture, I, 2. Available online at http:// www.americanpopularculture.com/journal/articles/fall_2002/contents.htm [Accessed 3 February 2009].

Harré, R. and Moghaddam, F. M. 2003. Introduction: the self and others in traditional psychology and in positioning theory. In Harré, R. and Moghaddam, F. M. (eds), The Self and Others: Positioning Individuals and Groups in Personal, Political, and Cultural Contexts. Praeger, Westport, Connecticut, I-I2.

Herrick, C. A., Pearcey, L. G. and Ross, C. I997. Stigma and ageism: compounding influences in making an accurate mental health assessment. Nursing Forum, 32, 3, 2 I-6.

Herskovits, E. 1995. Struggling over subjectivity debates about the 'self' and Alzheimer's disease. Medical Anthropology Quarterly, 9, 2, I46-64.

Higashi, S. I990. Night of the Living Dead: a horror film about the horrors of the Vietnam era. In Dittmar, L. and Michaud, G. (eds), From Hanoi to Hollywood: The Vietnam War in American Film. Rutgers University Press, Piscataway, New Jersey, I75-88.

Higgins, A. 20I0. Have we become posthuman digital zombies? Pittsburgh Post-Gazette, 24 January, Bi.

Hughes, J. C., Louw, S. J. and Sabat, S. 20o6. Seeing whole. In Hughes, J. C., Louw, S. J. and Sabat, S. (eds), Dementia: Mind, Meaning, and the Person. Oxford University Press, Oxford, I-39.

Johnson, H., Bouman, W. P. and Pinner, G. 200o. Dementia: on telling the truth in Alzheimer's disease: a pilot study of current practice and attitudes. International Psychogeriatrics, I 2, 2, 22I-9.

Jolley, D. J. and Benbow, S. M. 2000. Stigma and Alzheimer's disease: causes, consequences and a constructive approach. International fournal of Clinical Practice, 54, 2, II7-9.

Kessler, L. 2007. Dancing with Rose: Finding Life in the Land of Alzheimer's. Viking, New York.

Kittay, E. F. 1999. Love's Labor: Essays on Women, Equality, and Dependency. Routledge, New York.

Kitwood, T. I990. The dialectics of dementia: with particular reference to Alzheimer's disease. Ageing \& Society, ro, I77-96.

Kitwood, T. 1997. Dementia Reconsidered: The Person Comes First. Open University Press, Philadelphia, Pennsylvania.

Kontos, P. 2003. 'The painterly hand': embodied consciousness and Alzheimer's disease. Journal of Aging Studies, I 7, I5 I-70. 
Kuhse, H. 200I. Some reflections on the problem of advance directives. In Thomasa, D. G., Weisstub, D. N. and Hervé, C. (eds), Personhood and Health Care. Kluwer Academic, Dordrecht, The Netherlands, 265-79.

Larkin, W. S. 2006. Res corporealis: persons, bodies, and zombies. In Greene, R. and Mohammad, K. S. (eds), The Undead and Philosophy: Chicken Soup for the Soulless. Open Court, Chicago, Illinois, $\mathrm{I}^{-2}-2$.

Laurance, J. 20I0. Scientists read the minds of the living dead. The Independent (London), 4 February, i6.

Lushin, G. I99o. The Living Dead: Alzheimer's in America. National Foundation for Medical Research, Potomac, Maryland.

Lyman, K. A. I989. Bringing the social back in: a critique of the biomedicalization of dementia. The Gerontologist, 29, 5, 597-605.

Macfarlane, M. 2008. 'RNA computer' creates zombie cells. Cosmos, I7 October. Availble online at http://www.cosmosmagazine.com/news/2258/rna-computer-createszombie-cells [Accessed i9 February 2010].

Marker, R. and Smith, W. J. I996. The art of verbal engineering. Duquesne Law Review, 35, I, 8I-IO7.

Matthews, E. 2006. Dementia and the identity of the person. In Hughes, J. C., Louw, S. J. and Sabat, S. (eds), Dementia: Mind, Meaning, and the Person. Oxford University Press, Oxford, $163-77$.

McGowin, D. F. 1993. Living in the Labyrinth: A Personal Fourney Through the Maze of Alzheimer's. Delta, New York.

Netten, A. 1993. A Positive Environment? Physical and Social Influences on People with Senile Dementia in Residential Care. Ashgate, Aldershot, UK.

Niehaus, I. 2007. Death before dying: understanding AIDS stigma in the South African low veld. Fournal of Southern African Studies, 33, 4, 845-6o.

Nussbaum, M. C. 2010. From Disgust to Humanity: Sexual Orientation and Constitutional Law. Oxford University Press, New York.

Oregon Department of Health Services (ODHS) 2009. Death with Dignity Act Annual Report. Table I, ODHS, Salem, Oregon. Available online at http://www.oregon.gov/DHS/ ph/pas/ar-index.shtml [Accessed I2 March 2009].

Paffenroth, K. 2006. Religious themes of George Romero's zombie movies. GOLEM, Spring. Available online at http://www.golemjournal.org/Springo6_issue.htm [Accessed 6 June 20I0].

Phinney, A. and Chesla, C. A. 2003. The lived body in dementia. Fournal of Aging Studies, I 7, $3,283-99$.

Post, S. G. 2006. Respectare: Moral respect for the lives of the deeply forgetful. In Hughes, J. C., Louw, S. J. and Sabat, S. (eds), Dementia: Mind, Meaning, and the Person. Oxford University Press, Oxford, 223-34.

Rimsky, D. 2003. A Cautionary Tale. Customer review of Death in Slow Motion by E. Cooney. Amazon.com website, unpaginated. Available online at http://www.amazon.com/ Death-Slow-Motion-Daughter-Alzheimers/dp/BoooGG 4 FHM/ref=sr_I_I?ie $=$ UTF8\&s=

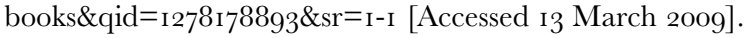

Robertson, A. I99I. The politics of Alzheimer's disease: a case study in apocalyptic demography. In Minkler, M. and Estes, C. L. (eds), Critical Perspectives on Aging: The Political and Moral Economy of Growing Old. Baywood, Amityville, New York, I35-50.

Rogowski, S. 2008. Are we all zombies now? Community Care, I 720, i May, 8.

Russell, J. 2005. Book of the Dead: The Complete History of Zombie Cinema. FAB Press, Godalming, UK.

Sabat, S. R. 2003. Malignant positioning and the predicament of people with Alzheimer's disease. In Harré, R. and Moghaddam, F. M. (eds), The Self and Others: Positioning 
Individuals and Groups in Personal, Political, and Cultural Contexts. Praeger, Westport, Connecticut, 85-99.

Schneider, D. J. 2005. The Psychology of Stereotyping. Guilford Press, New York.

Scholl, J. M. and Sabat, S. R. 2008. Stereotypes, stereotype threat and ageing: implications for the understanding and treatment of people with Alzheimer's disease. Ageing $\mathcal{E}^{\circ}$ Society, 28, I, I03-30.

Schuman, W. H. I99. Hospice care of the living dead: mental illness and our practices of care. Nursing and Healthcare, I 2, I0, 544-5.

Seabrook, W. I929. Magic Island. Harcourt, New York.

Sedgwick, E. K. I990. Epistemology of the Closet. University of California Press, Berkeley, California.

Shenk, D. 2001. The Forgetting: Alzheimer's: Portrait of an Epidemic. Anchor, New York.

Silberfeld, M. 200 r. Vulnerable persons. In Thomasa, D. C., Weisstub, D. N. and Hervé, C. (eds), Personhood and Health Care. Kluwer Academic, Dordrecht, The Netherlands, 299-316.

Smith, D. H. 1992. Seeing and knowing dementia. In Binstock, R. H., Post, S. G. and Whitehouse, P.J. (eds), Dementia and Aging: Ethics, Values, and Policy Choices. Johns Hopkins University Press, Baltimore, Maryland, 44-54.

Smith, R. 2009. Faux review: a report on the zombie outbreak of 2009: how mathematics can save us (no, really). Canadian Medical Association fournal, I81, I2, E297-300.

Snyder, L. I999. Speaking Our Minds: Personal Reflections from Individuals with Alzheimer's. W. H. Freeman, New York.

Sparrow, R. 2006. Right of the living dead? Consent to experimental surgery in the event of cortical death. Fournal of Medical Ethics, 32, I0, 601-5.

Thompson, C. 2009. Zombie-attack science. New York Times Magazine, i3 December, 70.

Thompson, J. 2006. Relatives of the living dead. Fournal of Medical Ethics, 32, I0, 6o7-8.

Thornhill, J., Clements, D. and Neeson, J. 2008. Myths, 'zombies' and 'damned lies' plague Canadian healthcare systems: what's a researcher to do? Healthcare Quarterly I I, $3, \mathrm{I} 4^{-15}$.

Tronto, J. I993. Moral Boundaries: A Political Argument for an Ethic of Care. Routledge, New York.

Twitchell, J. B. 1985. Dreadful Pleasures: An Anatomy of Modern Horror. Oxford University Press, Oxford.

Vance, E. 2007. Syllabus: zombies in popular media. Chronicle of Higher Education, 53, 25, Aio.

Wendell, S. I989. Toward a feminist theory of disability. Hypatia, 4, 2, I04-24.

Wood, R. 2008. Fresh meat: diary of the dead may be the summation of George A. Romero's zombie cycle (at least until the next installment). Film Comment. Available online at http://filmlinc.com/fcm/jfo8/deaddiary.htm [Accessed 7 March 2009].

Woods, R. T. 1989. Alzheimer's Disease: Coping with a Living Death. Souvenir, London.

\section{Accepted 20 July 20Io; first published online I7 September 2010}

Address for correspondence:

Susan M. Behuniak, Department of Political Science, Le Moyne College, Syracuse, NY I32 I4, USA.

E-mail: behuniak@lemoyne.edu 